\title{
Revista da FAEEBA: Educação e Contemporaneidade
}

ISSN 0104-7043

Revista temática quadrimestral do Departamento de Educação I - UNEB

\section{Normas para publicação}

\section{I - PROPOSTA EDITORIAL}

A Revista da FAEEBA: Educação e Contemporaneidade, seguindo as diretrizes nacionais de periódicos qualificados, a partir de 2016, passa a ser quadrimestral, mantendo na sua estrutura uma seção Temática e uma seção Estudos, em ambas publicando artigos inéditos, de natureza científica, resultantes de pesquisas que contribuam para o conhecimento teórico, metodológico e prático no campo da Educação e em interação com as demais Ciências Sociais, relacionando-se com a comunidade regional, nacional e internacional. Aceita trabalhos originais, que analisam e discutem assuntos de interesse científico-cultural. Está organizada nas seguintes seções:

- Temática

- Estudos

- Documentos

Nas seções Temática e Estudos cabem ensaios (estudos teóricos, com análise de conceitos) e resultados de pesquisa (artigos baseados em pesquisas finalizadas ou em andamento), sendo que na primeira caberão artigos articulados necessariamente com a temática específica do número (informação sempre disponível na página web), e na segunda, artigos atinentes a diversas temáticas dentro da proposta editorial da revista e recebidos em fluxo contínuo. A seção Documentos está aberta à publicação de resenhas (revisão crítica de uma publicação recente), entrevistas (com cientistas e pesquisadores renomados); estudos bibliográficos (análise crítica e abrangente da literatura sobre tema definido) e análises críticas de Projetos e Diretrizes da Área de Educação.

Os trabalhos devem ser inéditos, não sendo permitido o encaminhamento simultâneo para outros periódicos. A titulação mínima para os autores é o mestrado. Mestrandos podem enviar artigos desde que em coautoria com seus orientadores.

A revista recebe artigos redigidos em português, espanhol, francês e inglês, sendo que os pontos de vista apresentados são da exclusiva responsabilidade de seus autores. Os originais em francês e inglês poderão ser traduzidos para o português, com a revisão realizada sob a coordenação do autor ou de alguém indicado por ele. Os autores e coautores que tiverem artigos publicados devem ficar, no mínimo, com um intervalo de dois números sem publicar. Os textos não devem exceder a três autores.

A Revista recebe artigos em fluxo contínuo e direcionados para a Seção Temática (temas dos futuros números e os prazos para a entrega dos textos são publicados nos últimos números da revista), assim como no site www.revistadafaeeba.uneb.br

\section{II - RECEBIMENTO E AVALIAÇÃO DOS TEXTOS}

Os textos recebidos são apreciados inicialmente pelo editor executivo, que enviará aos autores a confirmação do recebimento. Se forem apresentados de acordo com as normas da Revista da FAEEBA: Educação e Contemporaneidade, serão encaminhados para os membros do Conselho Editorial ou para pareceristas ad hoc de reconhecida competência na área, sem identificação da autoria para preservar isenção e neutralidade de avaliação. 
Os pareceres têm como finalidade atestar a qualidade científica dos textos para fins de publicação e são apresentados de acordo com as quatro categorias a seguir: a) publicável sem restrições; b) publicável com restrições; c) publicável com restrições e sugestões de modificações, sujeitas a novo parecer; d) não publicável. Os pareceres são encaminhados para os autores, igualmente sem identificação dos pareceristas.

Os textos com parecer b) ou c) deverão ser modificados de acordo com as sugestões do conselheiro ou parecerista $a d$ hoc, no prazo a ser definido pelo editor executivo, em comum acordo com o(s) autor(es). As modificações introduzidas no texto, com o parecer b), deverão ser colocadas em vermelho, para efeito de verificação pelo editor executivo.

Após a revisão gramatical do texto, a correção das referências e a revisão dos resumos em língua estrangeira, o(s) autor(es) receberão o texto para uma revisão final no prazo de sete dias, tendo a oportunidade de introduzir eventuais correções de pequenos detalhes.

\section{III - DIREITOS AUTORAIS}

O encaminhamento dos textos para a revista implica a autorização para publicação. A aceitação da matéria para publicação implica na transferência de direitos autorais para a revista. A reprodução total ou parcial (mais de 500 palavras do texto) requer autorização por escrito da comissão editorial. Os autores dos textos assumem a responsabilidade jurídica pela divulgação de entrevistas, depoimentos, fotografias e imagens.

Os textos aprovados na Revista da FAEEBA: Educação e Contemporaneidade serão publicados na seção Temática ou na seção Estudos, e o número de artigos para cada seção dependerá da disponibilidade de espaço em cada número. Artigos podem ser aprovados mas não publicados na Revista em curso. Neste caso, os artigos aprovados passam a compor um "banco de artigos" e poderão integrar um futuro número. Se, depois de um ano, não surgir uma perspectiva concreta de publicação do texto, o artigo pode ser liberado para ser publicado em outro periódico, a pedido do(s) autor(es).

O autor principal de um artigo receberá três exemplares da edição em que este foi publicado, e aos autores que publicarem na Seção Documentos será destinado um exemplar. (No caso de o artigo ser escrito em coautoria, cada autor receberá dois exemplares)

\section{IV - ENCAMINHAMENTO E APRESENTAÇÃO DOS TEXTOS}

Os textos devem ser encaminhados para a Plataforma www.revistadafaeeba.uneb.br e para o endereço eletrônico do editor executivo (fialho2021@gmail.com / livia.fialho@yahoo.com.br). O mesmo procedimento deve ser adotado para os contatos posteriores. Ao encaminhar o texto, neste devem constar: a) a indicação de uma das modalidades citadas no item I; b) a garantia de observação de procedimentos éticos; c) a concessão de direitos autorais à Revista da FAEEBA: Educação e Contemporaneidade.

Os trabalhos devem ser apresentados segundo as normas definidas a seguir:

1. Na primeira página devem constar: a) título do artigo; b) nome(s) do(s) autor(es), endereços residencial (somente para envio dos exemplares dos autores) e institucional (publicado junto com os dados em relação a cada autor), telefones (para contato emergencial), e-mail; c) titulação principal; d) instituição a que pertence (m) e cargo que ocupa(m); e) grupo de pesquisa.

2. Resumo, Abstract e Resumen: cada um com no máximo 200 palavras, incluindo objetivo, método, resultado e conclusão. Logo em seguida, as Palavras-chave, Keywords e Palabras clave, cujo número desejado é de, no mínimo, três, e, no máximo, cinco. Traduzir, também, o título do artigo e do resumo, assim como do trabalho resenhado. Atenção: cabe aos autores entregar traduções de boa qualidade em inglês e em espanhol.

3. As figuras, gráficos, tabelas ou fotografias (em formato TIF, cor cinza, dpi 300), quando apresentados em separado, devem ter indicação dos locais onde devem ser incluídos, ser titulados e apresentar referências de sua autoria/fonte. Para tanto, devem seguir a Norma de apresentação tabular, estabelecida pelo Conselho Nacional de Estatística e publicada pelo IBGE em 1979. 
4. Sob o título Referências deve vir, após a parte final do artigo, em ordem alfabética, a lista dos autores e das publicações conforme as normas da ABNT (Associação Brasileira de Normas Técnicas). Vide os seguintes exemplos:

a) Livro de um só autor:

BENJAMIM, Walter. Rua de mão única. São Paulo: Brasiliense, 1986.

b) Livro até três autores:

NORTON, Peter; AITKEN, Peter; WILTON, Richard. Peter Norton: a bíblia do programador. Tradução de Geraldo Costa Filho. Rio de Janeiro: Campos, 1994.

c) Livro de mais de três autores:

CASTELS, Manuel. et al. Novas perspectivas críticas em educação. Porto Alegre: Artes Médicas, 1996.

d) Capítulo de livro:

BARBIER, René. A escuta sensível na abordagem transversal. In: BARBOSA, Joaquim (Org.). Multirreferencialidade nas ciências e na educação. São Carlos: EdUFSCar, 1998. p. 168-198.

e) Artigo de periódico:

MOTA, Kátia Maria Santos. A linguagem da vida, a linguagem da escola: inclusão ou exclusão? uma breve reflexão linguística para não linguistas. Revista da FAEEBA: educação e contemporaneidade, Salvador, v. 11, n. 17, p. 13-26, jan./jun. 2002.

f) Artigo de jornais:

SOUZA, Marcus. Falta de qualidade no magistério é a falha mais séria no ensino privado e público.

O Globo, Rio de Janeiro, 06 dez. 2001. Caderno 2, p. 4.

g) Artigo de periódico (formato eletrônico):

TRINDADE, Judite Maria Barbosa. O abandono de crianças ou a negação do óbvio. Revista Brasileira de História, São Paulo, v. 19, n. 37, 1999. Disponível em: <http://www.scielo.br>. Acesso em: 14 ago. 2000.

h) Livro em formato eletrônico:

SÃO PAULO (Estado). Entendendo o meio ambiente. São Paulo, 1999. v. 3. Disponível em: < http:// www.bdt.org.br/sma/entendendo/atual/htm>. Acesso em: 19 out. 2003.

i) Decreto, Leis:

BRASIL. Decreto n. 89.271, de 4 de janeiro de 1984. Dispõe sobre documentos e procedimentos para despacho de aeronave em serviço internacional. Lex: coletânea de legislação e jurisprudência, São Paulo, v. 48, p. 3-4, jan./mar, 1984. Legislação Federal e marginalia.

j) Dissertações e teses:

SILVIA, M. C. da. Fracasso escolar: uma perspectiva em questão. 1996. 160 f. Dissertação (Mestrado em Educação) - Faculdade de Educação, Universidade Federal de Minas Gerais, Belo Horizonte, 1996.

k) Trabalho publicado em Congresso:

LIMA, Maria José Rocha. Professor, objeto da trama da ignorância: análise de discursos de autoridades brasileiras, no império e na república. In: ENCONTRO DE PESQUISA EDUCACIONAL DO NORDESTE: história da educação, 13., 1997, Natal. Anais... Natal: EDURFRN, 1997. p. 95-107.

IMPORTANTE: Ao organizar a lista de referências, o autor deve observar o correto emprego da pontuação, de maneira que esta figure de forma uniforme.

5. O sistema de citação adotado por este periódico é o de autor-data, de acordo com a NBR 10520 de 2003. As citações bibliográficas ou de site, inseridas no próprio texto, devem vir entre aspas ou, quando ultrapassa três linhas, em parágrafo com recuo e sem aspas, remetendo ao autor. Quando o autor faz parte do texto, este deve aparecer em letra cursiva e submeter-se aos procedimentos gramaticais da língua. Exemplo: De acordo com Freire (1982, p. 35) etc. Já quando o autor não faz parte do texto, este deve aparecer no final do parágrafo, entre parênteses e em letra maiúscula, como no exemplo a seguir: "A pedagogia das minorias está à disposição de todos" (FREIRE, 1982, p. 35). As citações extraídas de sites devem, além disso, conter o endereço (URL) entre parênteses angulares e a data de acesso. Para 
qualquer referência a um autor deve ser adotado igual procedimento. Deste modo, no rodapé das páginas do texto devem constar apenas as notas explicativas estritamente necessárias, que devem obedecer à NBR 10520, de 2003.

6. As notas numeradas devem vir no rodapé da mesma página em que aparecem, assim como os agradecimentos, apêndices e informes complementares.

7. Os artigos devem ter, no máximo, $\mathbf{7 0}$ mil caracteres com espaços e, no mínimo, $\mathbf{4 5}$ mil caracteres com espaços; as resenhas podem ter até 30 mil caracteres com espaço. Os títulos devem ter no máximo 90 caracteres, incluindo os espaços.

8. As referências bibliográficas devem listar somente os autores efetivamente citados no corpo do texto.

Atenção: os textos só serão aceitos nas seguintes dimensões no processador Word for Windows ou equivalente:

- letra: Times New Roman 12

- tamanho da folha: A4

- margens: $2,5 \mathrm{~cm}$

- espaçamento entre as linhas: 1,5 ;

- parágrafo justificado.

Os autores são convidados a conferir todos os itens das Normas para Publicação antes de encaminhar os textos.

\section{Para contatos e informações:}

Administração:

Editor Geral: Augusto César Rios Leiro

E-mail: cesarleirocbce@gmail.com

Editora Científica: Lívia Fialho Costa

E-mail: fialho2021@gmail.com

Site da Revista da FAEEBA: https://www.revistas.uneb.br/index.php/faeeba 


\title{
Revista da FAEEBA: Educação e Contemporaneidade
}

\author{
ISSN 0104-7043
}

Quarterly thematic journal of the Education Faculty I - UNEB

\section{Norms for publication}

\section{I - EDITORIAL GUIDELINES}

Created in 1992, the FAEEBA: Education and Contemporaneity Journal, in keeping with national guidelines governing qualified periodicals, in 2016, it will be published quarterly, while continuing to maintain its present structure with both a Thematic section and one devoted to Studies. Both will feature original, previously unpublished articles of a scientific nature, based on research that contributes to theoretical, methodological, and practical knowledge in the field of Education. Our aim is to stimulate dialogues between various areas of the Social Sciences while forging relationships between regional, national, and international communities. The journal accepts original works that analyze and discuss issues of scientific and cultural interest. It is organized into the following sections:

- Thematic

- Studies

- Documents

The Thematic and Studies sections feature essays (theoretical studies, with analysis of concepts) and study results (articles based on ongoing or finalized research). For submissions to the Thematic section, articles must necessarily coincide with the specific topic chosen by that issue (information is available on the journal's web site). For the Studies section, articles exploring various topics that fall within the journal's editorial guidelines can be submitted at any time. The Documents section is open to the publication of reviews (critical reviews of recent publications); interviews (with recognized scientists and researchers); bibliographic studies (comprenhensive, critical analysis of literature on a defined theme) and critical analyses of Projects and Guidelines in the Area of Education.

Submitted works should be unpublished and should not be submitted simultaneously to other journal. Papers written in Portuguese, Spanish, French and English are received. Views published remain their authors' responsibility. Texts originally in French and English may be translated into Portuguese and published after a revision made by the author or by someone he has suggested. Authors who published in this journal should wait two volumes to become newly authorized to publish. No paper should have more than 3 authors.

The Journal accepts article submissions throughout the year for the Thematic Section (themes and submission deadlines for future issues are listed in recently published issues as well as on the site: www. revistadafaeeba.uneb.br

\section{II - RECEIVING AND EVALUATING SUBMITTED WORKS}

Texts submitted are initially appreciated by the Editor which will confirm reception. If they are edited in accordance with the norms, they will be sent, anonymously so to assure neutrality, to other member of the editorial committee or to ad hoc evaluators of known competence .

Evaluators' reports will confer the submitted work scientific quality and class them in four categories: a) publishable without restrictions b) publishable with restrictions; c) publishable with restrictions and modifications after new evaluation; d) unpublishable. Evaluators' reports are sent anonymously to the authors. 
In the b) or c) case, the works should be modified according to the report' suggestion in the terms determined by the editor in agreement with the authors. Modifications made should appear in red so as to permit verification.

After the grammatical revision of the text, the correction of the bibliography, and the revision of the part in English, the authors(s) will receive the text for an ultimate opportunity to make small corrections in a week.

\section{III - COPYRIGHTS}

Submitting text to the journal means authorizing for publication. Accepting a text for publication imply the transfer of copyrights to the journal. Whatever complete or partial reproduction (more than 500 hundreds words) requires the written authorization of the editorial committee. Papers' authors should assume juridical responsibility for divulging interviews, photographies or images.

Texts approved by the FAEEBA: Education and Contemporaneity Journal will be published in the Thematic or Studies sections; the number of articles in each section will be determined by available space in each issue. Articles may be approved, but not published in an upcoming issue. In this case, they with be kept in an "article bank" and may be published in a future issue. After one year, if there is no concrete possibility of a text's being published, authors may request permission to publish it in another periodical.

The main author of a paper will receive three copies of the volume in which his paper was published. The author of an abstract or a review will receive one.

\section{IV - SENDING AND PRESENTING WORKS}

Texts as well as ulterior communication should be sent exclusively to the e-mail address of the editor (fialho2021@gmail.com). In should be explicited initially a) at which modality the text pertains; b) ethical procedures; c) copyrights concession to the Revista da FAEEBA: Educação e Contemporaneidade.

Works should respect the following norms:

1. In the first page, should appear: a) the paper's title; b) authors' name, address, telephones, e-mail; c) main title; d) institutional affiliation and post.

2. Resumo, Abstract and Resumen: each with no more than 200 words including objective, method, results and conclusion. Immediately after, the Palavras-chave, Keywords and Palabras clave, which desired number is between 3 and 5. Authors should submit high quality translation.

3. Figures, graphics, tables and photographies (TIF, grey, dpi 300), if presented separately should come with indication of their localization in the text, have a title and indicates author and reference. In this sense, the tabular norms of tabular presentation, established by the Brazilian Conselho Nacional de Estatística and published by the IBGE in 1979.

4. Under the title Referências should appear, at the end of the paper, in alphabetic order, the list of authors and publication according to the norms of the ABNT (Associação Brasileira de Normas Técnicas). See the following examples:
a) Book of one author only:
BENJAMIM, Walter. Rua de mão única. São Paulo: Brasiliense, 1986.

b) Book of two or three authors:

NORTON, Peter; AITKEN, Peter; WILTON, Richard. Peter Norton: a bíblia do programador. Tradução de Geraldo Costa Filho. Rio de Janeiro: Campos, 1994.

c) Book of more than three authors:

CASTELS, Manuel et al. Novas perspectivas críticas em educação. Porto Alegre: Artes Médicas, 1996.

d) Book chapter: 
BARBIER, René. A escuta sensível na abordagem transversal. In: BARBOSA Joaquim (Org.). Multirreferencialidade nas ciências e na educação. São Carlos: EdUFSCar, 1998. p. 168-198.

e) Journal's paper:

MOTA, Kátia Maria Santos. A linguagem da vida, a linguagem da escola: inclusão ou exclusão? uma breve reflexão lingüística para não lingüistas. Revista da FAEEBA: educação e contemporaneidade, Salvador, v. 11, n. 17, p. 13-26, jan./jun. 2002.

f) Newspaper:

SOUZA, Marcus. Falta de qualidade no magistério é a falha mais séria no ensino privado e público. O Globo, Rio de Janeiro, 06 dez. 2001. Caderno 2, p. 4.

g) On-line paper :

TRINDADE, Judite Maria Barbosa. O abandono de crianças ou a negação do óbvio. Revista Brasileira de História, São Paulo, v. 19, n. 37, 1999. Available at: <http://www.scielo.br>. Acesso em: 14 ago. 2000.

h) E-book:

SÃO PAULO (Estado). Entendendo o meio ambiente. São Paulo, 1999. v. 3. Disponível em: < http:// www.bdt.org.br/sma/entendendo/atual/htm>. Acesso em: 19 out. 2003.

i) Laws:

BRASIL. Decreto n. 89.271, de 4 de janeiro de 1984. Dispõe sobre documentos e procedimentos para despacho de aeronave em serviço internacional. Lex: coletânea de legislação e jurisprudência, São Paulo, v. 48, p. 3-4, jan./mar, 1984. Legislação Federal e marginalia.

j) Thesis:

SILVIA, M. C. da. Fracasso escolar: uma perspectiva em questão. 1996. 160 f. Dissertação (Mestrado) - Faculdade de Educação, Universidade Federal de Minas Gerais, Belo Horizonte, 1996.

k) Congress annals:

LIMA, Maria José Rocha. Professor, objeto da trama da ignorância: análise de discursos de autoridades brasileiras, no império e na república. In: ENCONTRO DE PESQUISA EDUCACIONAL DO NORDESTE: história da educação, 13, 1997. Natal. Anais... Natal: EDURFRN, 1997. p. 95-107.

IMPORTANT: Organizing references, the author should take care of punctuation correct use, so as to preserve uniformity.

5. This journal use the author-date quote system, according to the NBR 10520 de 2003. Bibliographical quotes or quotes from on-line publications, if inserted into the text, should appear between quotation marks or if the quotation is more than three lines long, distanced and without quotation marks with author reference. Examples: 1- According to Freire (1982: p.35), etc. 2-Minority pedagogy is for all (Freire, 1982, p.35). On-line quotes should indicate the URL and access date. Footnotes should only contain explanatory notes strictly necessary respecting the NBR 10520, of 2003.

6. Texts can contain footnotes, thanks, annexes and complementary informations.

7. Articles must have a minimum of $\mathbf{4 5 , 0 0 0}$ characters and a maximum of $\mathbf{7 0 , 0 0 0}$ characters (with spaces). Reviews can be up to $\mathbf{3 0 , 0 0 0}$ characters (with spaces). Titles should have no more than 90 characteres including spaces. Reviews are limited to 5 pages. Thesis abstracts should contain no more than 250 words and should include title, number of page, author data, key-words, name of the director and university affiliation, as well as the date of the defense and the English translation of text, abstract and key-words.

Look out: texts will only be accepted formated in Word for Windows or equivalent:

font: Times New Roman 12

paper dimension: A4

margins: $2,5 \mathrm{~cm}$

line spacing: 1,5 ;

paragraph justified.

Authors are invited to check the norms for publication before sending their work. 


\section{Contact and informations:}

General Editor: Augusto César Rios Leiro - E-mail: cesarleirocbce@gmail.com

Executive Editor: Lívia Fialho Costa - E-mail: fialho2021@gmail.com

Website of the Revista da FAEEBA: https://www.revistas.uneb.br/index.php/faeeba 